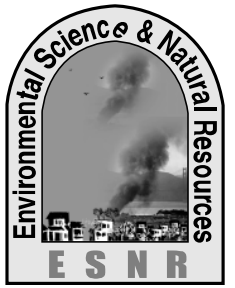

J. Environ. Sci. \& Natural Resources, 5(2): 267 - 274, 2012

ISSN 1999-7361

\title{
Contributions of Agroforestry Practice Towards Reducing Poverty at Keshabpur Upazila of Jessore District - A Case Study
}

\author{
M. W. Islam, M. M. Islam and M. N. Sadath
}

Forestry and Wood Technology Discipline, Khulna University, Khulna 9208, Bangladesh

\begin{abstract}
The systematic agroforestry practice is being popular day by day in Jessore district of Bangladesh. Considering the situation, the present study aims to know the farmers' attitude and perception about agroforestry practice and to find out the potentialities of agroforestry to reduce poverty at the study area viz., Keshabpur upazila of Jessore district. Mixed method by using semistructured questionnaires was followed in the field survey. The results illustrated that the respondents preferred agricultural practice (average $58.45 \%$ of their total lands) as their major land use followed by homestead and agroforestry land uses (31.75\%). Agroforestry was getting popularity as well as socially and ecologically acceptable at this area due to the diversified outcomes of this practice. The small land holders (possession $>1$ acre) were the most interested among the respondents to practice agroforestry. The less poor agroforestry farmers' change of income was also higher than the poor farmers. The increased production and income facilitated the villagers to reduce their poverty to some extent and thus they had better access to their daily necessities which helped them to attain a minimal standard of living.
\end{abstract}

Key words: Agricultural crops, Households, Income, Land use, Perennial crops, Perception

\section{Introduction}

Bangladesh has 2.46 million ha of forestland covering about $17 \%$ of the country's area. Bangladesh Forest Department (FD) controls, manages and protects all state-owned forests except Unclassed Stated Forest (USF) (FD, 2012). More than $90 \%$ of the state-owned forest land is concentrated in 12 districts in the eastern and south-western regions of the country and out of 64 districts, 28 districts have no state-owned forest at all (GoB, 1990). Besides the traditional forestry practices in the forest lands, agroforestry practices in the croplands and homesteads play a vital roles in increasing tree coverage and to supply annual, perennial and animal products and services. Jessore is the district situated on the southwestern part of Bangladesh (BBS, 2012). There is no natural forest in this region having only $15 \%$ of village forest (private-owned) which is too small to meet the demands of per capita consumption of timber and fire wood for the population (Devidson, 1984). There are $48 \%$ to $60 \%$ people who are living under poverty line (upper line) (Anon, 2010). As the population of this area is increasing day by day so agroforestry can be an important land use system to meet the demand of forest produces and also to reduce the poverty for the people of this region. Considering the background the objectives of the present study are to know the farmers' attitude and perception about agroforestry practice and to find out the potentialities of agroforestry to reduce poverty at the study area.

\section{Materials and Methods}

Selection of study area: Keshabpur upazila or subdistrict (Fig. 1) of Jessore district (south-western part of Bangladesh) under Khulna division is a potential place for practicing agroforestry. A considerable portion of the population of this area is involved with agroforestry practice. So, Keshabpur upazila was selected as the study area purposively for the present study. Three villages (Nuton Mulgram, Komorpur and Jahanpur) of Keshabpur upazila were selected randomly where agroforestry is practiced.
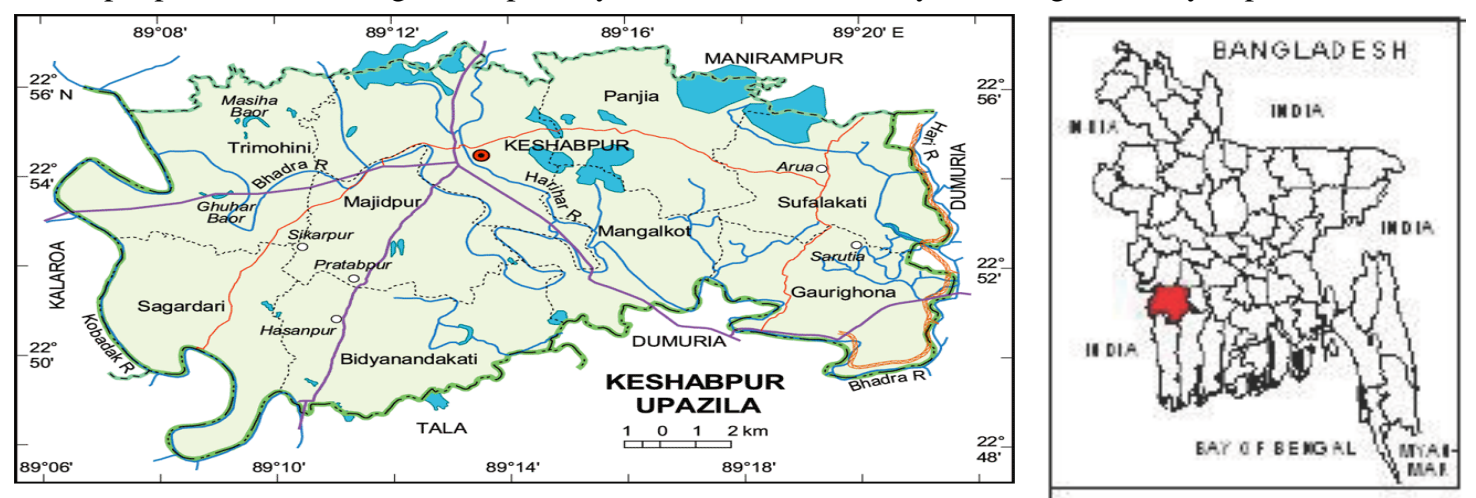

Fig. 1. Keshabpur upazila of Jessore district- the study area (Source: Banglapedia, 2006) 
About study area: The distance of Keshabpur upazila from Jessore city is $32 \mathrm{~km}$ which is located between $22^{\circ} 48^{\prime}$ and $22^{\circ} 57^{\prime} \mathrm{N}$ latitudes and between $89^{\circ} 07^{\prime}$ and $89^{\circ} 22^{\prime}$ E longitudes covering an area of $258.52 \mathrm{~km}^{2}$. It consists of 143 villages under 9 unions. This upazila is surrounded by Manirampur upazila to the north, Tala and Dumuria upazila to the south, Dumuria upazila also covers the southeast part and Kalarua upazila is to the west. The total population of this upazila was (according to Population Census 2001) 2,26,367 (male 51.36\%, female $48.64 \%$, ration 106:100) having the density of $875 / \mathrm{km}^{2}$ consisting of total 49,900 households and where the annual growth rate was 1.23 .

Data collection method: The focus of the study was to know the farmers' attitude and perceptions regarding practicing agroforestry at Keshabpur upazila of Jessore district. So, the farmer of this study area was selected as the target population and the primary data were collected from the field survey using mixed method followed by semi-structured questionnaire. Due to unavailable of reliable data on the farmers who practice in this study area random sampling was not possible in the field. As a result snowball purposive sampling method was used to collect the field data. The sample size of the study was 80 where the farmers who practiced agroforestry were the sampling units. Mixed method was used to collect the field data. Farmers' attitude and perceptions regarding practicing agroforestry were viewed from different angles along with their socioeconomic characteristics by the help of the questionnaire. Different indicators for assessing the contributions of agroforestry practice in reducing poverty at the study area were selected for this study. These indicators were: income status, educational status, housing condition, sanitation condition, household assets status, production of agricultural crops, homestead and cropland agroforestry species and perception on importance of trees. The field survey was carried out in 2004-05.

Types of data collection and analysis: Two types of data were collected for this study. a. Primary data: Field survey was carried out through formal and informal face-to-face individual interview with the respondents (local households/farmers) of the targeted study area and $b$. Secondary data: Information were collected from different libraries of Khulna University, journals and magazines, published and unpublished national and international reports, websites, etc. The collected data were reviewed, sorted and analyzed systematically considering the objectives of the study. MS Excel package was used to analyze these survey data.

\section{Results and Discussions}

The findings along with the discussions related to poverty alleviation through agroforestry practice at the study area based on the field survey have been presented in the section.

\section{Family size}

The average family size of the targeted households i.e., respondents of the three studied villages (viz. Nuton Mulgram, Komorpur and Jahanpur) of Keshabpur upazila has been shown in Table 1 on the basis of their age and sex. The average no. of male family members (2.72) is higher than the same of female (2.14) in these villages. The average household size of the respondents was found as 4.86 members. The average family size in Bangladesh is 4.84 members (BBS, 2005). So, the average family size of the study area was slightly higher than the national average at that time.

Table 1. Family size of the respondents by sex and age.

\begin{tabular}{|c|c|c|c|c|c|c|c|c|c|c|c|c|}
\hline \multicolumn{10}{|c|}{ Avg. no. of family members of the respondents by sex \& age (yrs.) } & \multirow{2}{*}{\multicolumn{2}{|c|}{ Total }} & \multirow{3}{*}{$\begin{array}{l}\text { *Avg. family } \\
\text { size (no.) }\end{array}$} \\
\hline \multicolumn{2}{|c|}{ Up to 15} & \multicolumn{2}{|c|}{$15+$ to 30} & \multicolumn{2}{|c|}{$30+$ to 45} & \multicolumn{2}{|c|}{$45+$ to 60} & \multicolumn{2}{|c|}{$60+$} & & & \\
\hline $\mathrm{M}$ & $\mathrm{F}$ & M & $\mathrm{F}$ & $M$ & $\mathrm{~F}$ & $\mathrm{M}$ & $\mathrm{F}$ & $\mathrm{M}$ & $\mathrm{F}$ & $\mathrm{M}$ & $\mathrm{F}$ & \\
\hline 0.85 & 0.82 & 0.82 & 0.55 & 0.65 & 0.52 & 0.27 & 0.15 & 0.13 & 0.1 & 2.72 & 2.14 & 4.86 \\
\hline
\end{tabular}

\section{Land status}

Land status of the respondent households surveyed to indicate their economic condition. Their land holding status has been categorized under the extent of homestead, agroforestry, agriculture and other land. The results showed (Table 2) that $32.5 \%$ households had only less than 1 acre of land where $42.17 \%$ of land were used as agricultural practice, $27.71 \%$ for agroforestry, $18.07 \%$ for homestead practice and the rest $(12.05 \%)$ were for the other land use purposes. Most of the respondents $(42.5 \%)$ were under the category of land size 1 to $>2.5$ acre. As a result, three- 
fourth of the respondents had less than 2.5 acres of land and the rest one-fourth had more than 2.5 acres of land. Among the different land use categories agricultural practice was predominant $(58.45 \%)$ over other land uses followed by homestead (17.14\%), agroforestry $(14.61 \%)$ and other land uses $(9.79 \%)$. It was noted that there was no landless respondent.

Table 2. Different categories of land uses of the respondent households

\begin{tabular}{ccccccc}
\hline \multirow{2}{*}{$\begin{array}{c}\text { Amount } \\
\text { of land }( \\
\text { in acre) }\end{array}$} & No. of respondents & \multicolumn{5}{c}{ Average hand (in acre) for different land uses } \\
\cline { 3 - 6 } & & Homestead & Agroforestry & Agriculture & Others & Total \\
\hline $\begin{array}{c}\text { Less than } \\
1\end{array}$ & $26(32.5)$ & $0.15(18.07)^{*}$ & $0.23(27.71)$ & $0.35(42.17)$ & $0.1(12.05)$ & \\
1 to $>2.5$ & $34(42.5)$ & $0.41(20.81)$ & $0.34(17.26)$ & $1.07(54.31)$ & $0.15(7.61)$ & 1.97 \\
2.5 to $>5$ & $10(12.5)$ & $0.59(16.43)$ & $0.50(13.93)$ & $2.14(59.61)$ & $0.36(10.03)$ & 3.59 \\
$\quad \begin{array}{c}\text { More } \\
\text { than 5 }\end{array}$ & $10(12.5)$ & $1.02(16.27)$ & $0.78(12.44)$ & $3.84(61.24)$ & $0.63(10.05)$ & 6.27 \\
\hline Total & $80(100)$ & $2.17(17.14)$ & $1.85(14.61)$ & $7.4(58.45)$ & $1.24(9.79)$ & 12.66 \\
\hline
\end{tabular}

* The figures in the parentheses are in percentage

\section{Increasing income}

The average monthly income distribution of the respondents has been divided into four income groups in two time frame viz. before practicing agroforestry and after practicing agroforestry (Table 3). It is clear from this table that the average monthly income of the respondent households has been increased after practicing the agroforestry. The result showed, of the total respondents' $50 \%$ households' income were $\mathrm{Tk}$. 1600.00 per month before practicing agroforestry but after practicing agroforestry for few years their monthly income increased (12.5\%) to Tk. 1800.00. The average change of income of the respondents was $14.39 \%$ due to their agroforestry practices. It may be commented here that the rich farmers/households having income more than Tk. 5000.00 per month have been benefited more by agroforestry practices than the lower income groups. But it needs further study in details to confirm and generalize it.

Table 3. Income of targeted households of the study area.

\begin{tabular}{ccccc}
\hline $\begin{array}{c}\text { Monthly } \\
\text { income (Tk.) }\end{array}$ & $\begin{array}{c}\text { No. of } \\
\text { households }(\%)\end{array}$ & $\begin{array}{c}\text { Avg. monthly income } \\
\text { (Tk.) before practicing } \\
\text { AF }\end{array}$ & $\begin{array}{c}\text { Avg. monthly income } \\
\text { (Tk.) after practicing AF }\end{array}$ & $\begin{array}{c}\text { Avg. income } \\
\text { change }(\%)\end{array}$ \\
\hline$>2000$ & $40(50)$ & 1600 & 1800 & 12.50 \\
$2000-3500$ & $20(25)$ & 2650 & 3000 & 13.21 \\
$3500-5000$ & $12(15)$ & 3900 & 4350 & 11.54 \\
$<5000$ & $8(10)$ & 6100 & 7150 & 17.21 \\
\hline Total/Avg. & $80(100)$ & 3562.5 & 4075 & 14.39 \\
\hline
\end{tabular}

It may be noted here that this change percentage has been calculated according to the information provided by the respondents which may not be the exact figure. Generally they didn't record their income black and white with particular reference to agroforestry. But as they were requested to memorize their income status before and after their agroforestry practices so they tried to memorize as much as possible to cooperate this research study.

\section{Educational status}

As mentioned in the previous section of income status of the respondents resulted from the agroforestry practice that this practice had played positive roles in developing education at the study area. The extra income of these household respondents facilitated them to invest their money into educational purposes of their children and even for themselves (adult education). The following figure (Fig. 2) shows the status of education of the respondents' family members (who were 6 years old) before starting agroforestry practice in their area. These respondents were asked to identify the contributions of agroforestry practices in their education aspect. But it was very difficult for them to segregate the particular effects of this practice in their education level as their might be some other extraneous factors to control their education level. Nevertheless, they confessed undoubtedly that this agroforestry has effects to reduce their illiteracy and better access in their education. In spite of the problem efforts were taken in the field if it was possible to identify the impacts of 
agroforestry practices in their education. The field survey result shows that about $6.37 \%$ of the total targeted households were illiterate or had no schooling before practicing agroforestry but after practicing agroforestry there was only $0.96 \%$ illiterate. Similarly this practice increased the other levels (Fig. 2) of education for the respondents' family members.

\section{Housing condition}

Housing condition of the targeted households was taken into consideration to analyze the effects of agroforestry in the study area. In this regard, the respondents were interviewed to know the construction materials (e.g., soil, brick, bamboo, wood, galvanized iron, etc.) used for building their houses (particularly floor, wall and roof). The filed survey result showed that before introducing agroforestry practice $28.75 \%$ of the respondents had no well maintained house mainly constructed by soil and straw and after practicing agroforestry this percentage reduced to $22.5 \%$ (Fig. 3). It meant that they had better income through agroforestry practice which they utilized for their better housing condition. They spent some portions of their increased income into the betterment of their housing condition which was also an indicator for their better living status. The other two categories were also found to increase as building materials of the respondents (see Fig. 3).

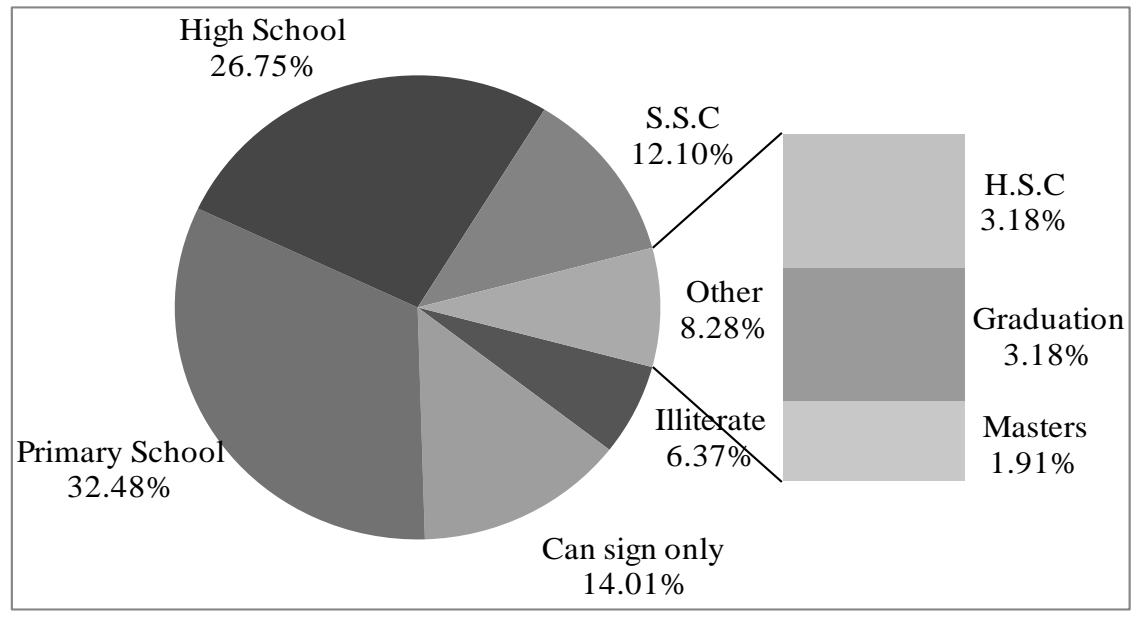

Fig. 2. Educational status of the targeted household family members (above 6 years).

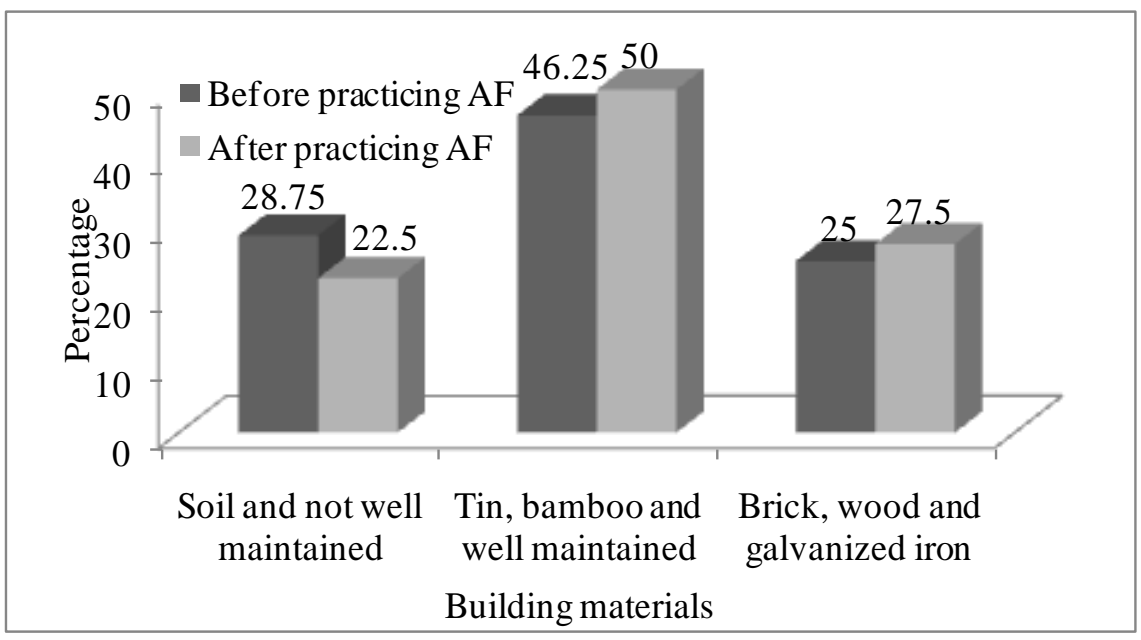

Fig. 3. Housing condition of the targeted households. 


\section{Sanitation condition}

The effects of agroforestry practice on sanitation condition of the targeted households were studied under the research. It was noticed that before practicing agroforestry 27.5\%, $42.5 \%$ and $30 \%$ households' (Fig. 4) latrines were made by soil, chari and sanitary respectively. These percentages were changed into $17.5 \%, 36.25 \%$ and $46.25 \%$ respectively after practicing agroforestry practice. So, this result explains that the sanitation condition of the respondents was improved due to the earning from agroforestry which also indicates the healthy and hygiene environment of their living places.

\section{Status of the household assets}

The targeted households were interviewed regarding their household assets. These assets were bicycle, motorcycle, van/rickshaw, television, tube well, pump machine, cow, goat, etc. The results showed that these assets were increased (Fig. 5) due to practicing agroforestry in the study area. The under-stated figure depicts that the number of van/rickshaw has increased 100 times after agroforestry practice than before practicing this. As the poor people were benefited by agroforestry practice and so they utilized their income to buy van/rickshaw so that they could earn some extra money by renting it or by driving it by themselves. Similarly they bought motor bike $(60 \%$ more than before practicing agroforestry) and bicycle (28\%) for their ease of communication and also for their recreation. Buying television (78\%) being a recreational tool was another important indicator for their better living condition. Following the same fashion they bought more pump machine $(59 \%)$ for irrigation, tube well $(58 \%)$ for their safe drinking water, goat $(39 \%)$ and cow (32\%) for getting milk and some extra income. These increased household assets were playing an important role for their safety net and reducing their poverty as well as to improve their living quality.

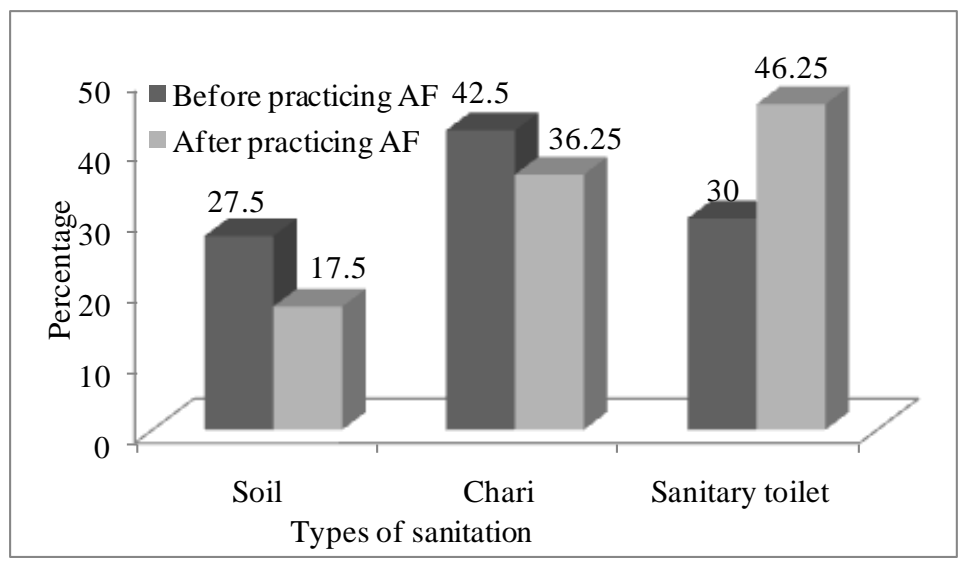

Fig. 4. Sanitation condition of the households.

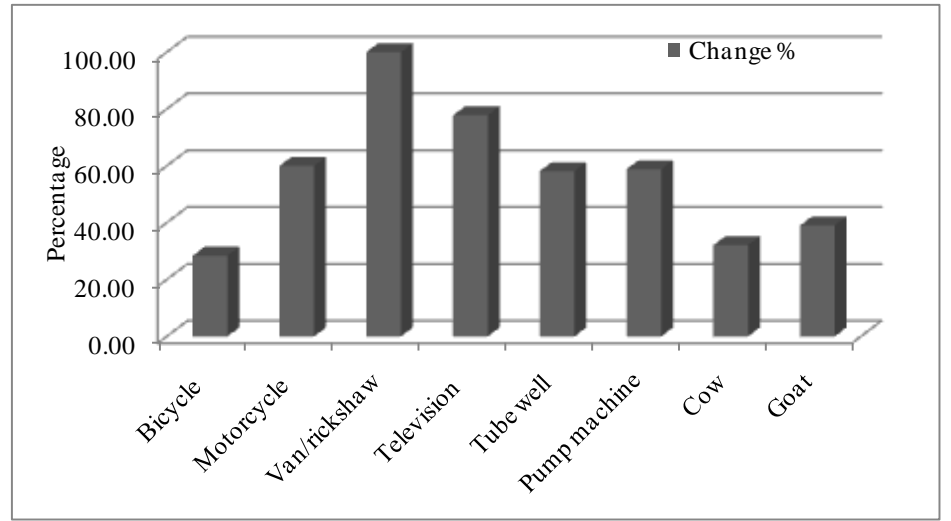

Fig. 5. Changes in assets possessions of the respondents 


\section{Production of agricultural crops}

The respondents opined, there was little impact of trees on the agricultural crops. As a result, there was no considerable variation of annual crop production in agroforestry practice at the study area. Consequently, keeping the annual crop production more or less same they get some extra benefits and incomes derived from the trees of same piece of land. The results showed that sesame was most profitable agricultural crop in the agroforestry practice (Table 4). The Benefit-Cost Ratio (BCR) was 6.20 which meant that by investing Tk. 1.00 the farmers got return back Tk. 6.20 for sesame species. Pea, jute, wheat and rice (aus) were next most profitable agricultural crops. The Net Present Value (NPV) of sesame was also highest among them which was Tk. 3120 which meant the farmers profited Tk. 3120 against Tk. 600 per bigha. In terms of production (per unit land), jute and rice (aus) were maximum (500 $\mathrm{Kg}$ ) but these were not profitable as sesame or pea which production were not so high. These two indicators of profit can facilitate the farmers of the study area to select the profitable agricultural crops in agroforestry practice which will maximize their benefits to reduce their poverty.

Table 4. Production of some major agricultural crops in agroforestry practice

\begin{tabular}{cccccc}
\hline $\begin{array}{c}\text { Name of } \\
\text { the crops }\end{array}$ & $\begin{array}{c}\text { Production per } \\
\text { bigha (Kg) }\end{array}$ & $\begin{array}{c}\text { Investment per } \\
\text { bigha (Tk.) }\end{array}$ & $\begin{array}{c}\text { Profit per } \\
\text { bigha (Tk.) }\end{array}$ & $\begin{array}{c}\text { Net Present } \\
\text { Value (NPV) }\end{array}$ & $\begin{array}{c}\text { Benefit-Cost } \\
\text { Ratio (BCR) }\end{array}$ \\
\hline Rice (Aus) & 500 & 1400 & 2600 & 1200 & 1.86 \\
Wheat & 450 & 1200 & 2400 & 1200 & 2.00 \\
Jute & 500 & 1300 & 3700 & 2400 & 2.85 \\
Pea & 260 & 1500 & 4220 & 2720 & 2.81 \\
Sesame & 240 & 600 & 3720 & 3120 & 6.20 \\
\hline
\end{tabular}

\section{Homestead tree species}

Diversified tree species were found in the homesteads (about 18 species) of the respondents. Among these species, mahagony was the dominant followed by jackfruit and mango. Most of the respondents choose mahagony for their excellent growth performance and high timer value. Jackfruit and mango were chosen due their food and timber value. The production performance of coconut and betel nut in this study area was considerably satisfied. The prevalence of date palm tree in this region was considered as the highest in Bangladesh. Most of the date palm molasses was produced in this region. Good production of date palm molasses and juice contributed handsome amount of money to the local people of this region. Moreover, the other species such as guava, blackberry, lemon, wood apple, palm, litchi, etc. (see Table 5) were also used significantly for their nutrition and timber value. These various homestead species played an important role to increase the diversified income of the respondents which contributed to reduce their poverty to some extent.

Table 5. Major tree species grown in the homesteads

\begin{tabular}{llll}
\hline English name & Scientific name & English name & Scientific name \\
\hline Mahogany & Swietenia mahagony & Sissoo & Dalbergia sissioo \\
Jackfruit & Artocarpus heterophyllus & Rain tree & Albizia lebbeck \\
Mango & Mangifera indica & Gamer & Gamelina arborea \\
Coconut & Cocos nucifera & Wood apple & Aegle marmelos \\
Betel nut & Areca catechu & Palm & Palmyra palm \\
Guava & Psidium guajava & Litchi & Litchi chinensis \\
Blackberry & Syzygium cumini & Neem & Azadiracta indica \\
Date palm & Phoenix sylvestris & Teak & Tectona grandis \\
Lemon & Citrus limon & Kadam & Anthocephalus cadamba \\
\hline
\end{tabular}

\section{Choice of crop species and livestock for agroforestry practice}

The main purpose of the agroforestry is to get annual (agricultural), perennial (fruit and timber) crops and/or livestock altogether from the same unit of land. Therefore, we have to consider their compatibility for getting these diversified products and services from a single piece of land. This compatibility relationship among these different biological and physical components is very crucial to maintain the production integrity among them otherwise the whole production system may collapse. 
Taking this into their consideration, people of this region freely choose date palm because it affected the crops less and it needed less space and shaded less and had no litter fall on the agricultural crop field. However, jackfruit was treated as a potential species for agroforestry but it took more space and shaded more which created problems for the agricultural crops. The species papaya used more in this region in agroforestry practice because it took very little space and casted very light shade which affected the crops very little. The respondents judged such different characteristics and relationships among the perennial crops and annual crops to select their species for the both types of crops. The other perennial species that the households preferred for their agroforestry practice were: mango, lemon, mahagony, jujube, sissoo and neem. The preferred annual crops were: rice, wheat, turmeric, potato, banana, giant taro, sweet gourd, lentil, garlic and bean. They also used these species for feeding their domestic animals (mostly cows and goats). Experiences and indigenous knowledge of the respondents played as determining factors for selecting the right crop species for their agroforestry practices which led them better production and income.

\section{Perceived importance of trees}

The respondents perceived the importance of the tress very positively (Fig. 6) after practicing agroforestry in their region. This perception was far positive than before practicing agroforestry. They perceived the importance of trees both for its tangible (different products and selling these products) and intangible benefits (environmental services). Introducing trees in the agricultural fields had grown more consciousness for them for its diversified benefits.

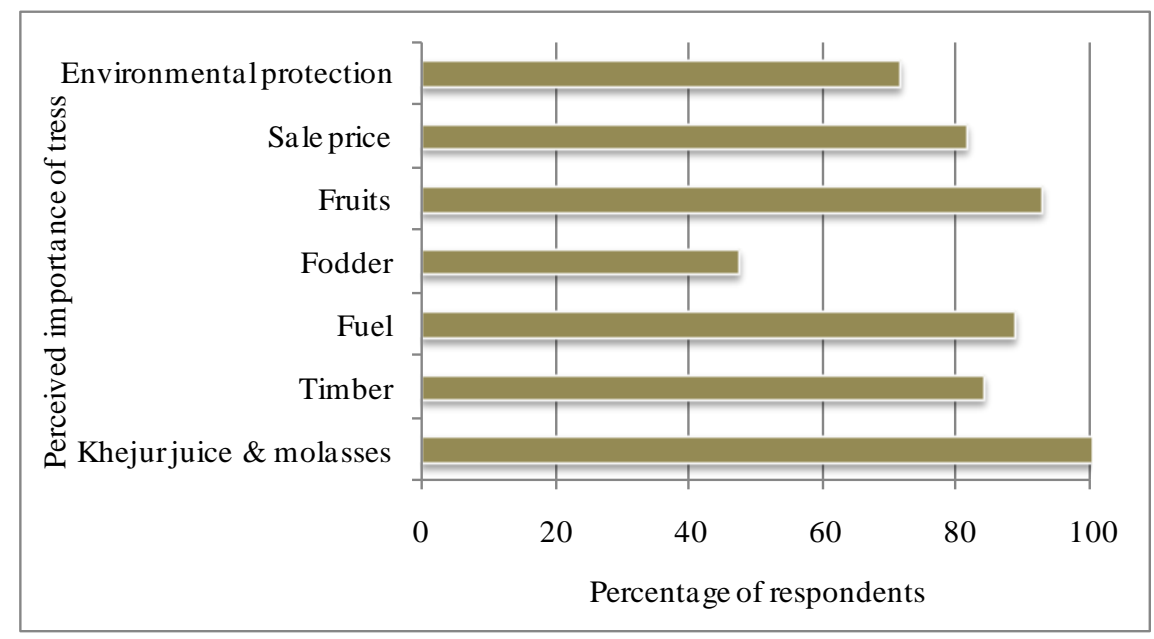

Fig. 6. Perceived importance of trees by the respondents

\section{Discussions}

Traditional agroforestry practice was prevailed in Jessore district since time immemorial. The systematic agroforestry practice is also being popular day by day in this region. The respondents of Keshabpur upazila of Jessore district preferred agricultural practice or annual cropping (average $58.45 \%$ of their total lands) as their major land use followed by homestead and agroforestry land uses $(31.75 \%)$. Agroforestry i.e., perennial cropping along with annual crops was getting popularity at this area day by day due to its diversified contributions to their socio-economic dimensions. This practice was socially and ecologically acceptable to the local people. It was very interesting that the small land holders (possession $>1$ acre) were the most interested among the respondents to practice agroforestry to get more benefits from this mixed (both annual and perennial) cropping system. They had very positive attitude on this practice and they perceived to get better return than mono cropping/agricultural practice. They believed that they could minimize the risk of damaging one crop(s) by the other crops. The growth of domestic animals in that area was also increased as the agroforestry practices served the fodder materials for these increased animals (mostly cattle). These animals were also contributing to earn some extra income as well as to provide necessary proteins for the poor people. The result also indicated that the comparatively rich farmers preferred agricultural practice more than other land uses. These farmers had other occupation or sources of income in addition to the agriculture. So, they were not as interested on practicing agroforestry as comparatively 
poor farmers of the study area. The less poor agroforestry farmers' change of income was also higher than the poor farmers as they invested more resources. The respondents noted that as they were practicing agroforestry since last few years so the returns from this practice was not so high as the trees were not felled in greater number. But at the same time, they opined that they expected greater income in the future when their agroforests would grow older and mature. Taking consideration of the income status of the respondents, it might be reckoned that the agroforestry practices (cropland and homestead agroforestry) of Keshabpur upazila were contributing an important role for the local people who were practicing it to increase their income to some extent. These increased incomes were also facilitating the respondents to upgrade their living status which provided them better access for food, education, shelter, health and cloth. They also opined that their social status had also been increased by this way and they were feeling better. These increased production (combined) and income (through providing new job opportunities) from agroforestry facilitated these villagers to reduce their poverty to some extent and thus they had better access to their daily necessities which helped them to attain a minimal standard of living. The subsistence and commercial uses of diversified products and services of agroforestry secured their food production, protecting a sound environment and conserving the biodiversity which also facilitated to conserve and protect traditional forest resources.

\section{Conclusions}

The present study indicated clearly that the respondents of Keshabpur upazila were very positive on practicing agroforestry in their croplands and homesteads. They perceived agroforestry as a profitable land use system which contributed them in many diversified ways such as: improving income, educational status, housing condition, homestead tree species status, household assets, sanitation condition, production of agricultural crops, etc. Their attitude and perception on agroforestry practice were very supportive to promote and upscale agroforestry in the study area. Moreover, they perceived the importance of trees immensely. These sorts of findings may conclude that the agroforestry practice is contributing positively to reduce poverty at Keshabpur upazila of Jessore district

\section{References}

Anonymous, 2010. Updating poverty maps of Bangladesh: Key findings. The World Bank, World Food Programme and BBS, 19 p.

Bangladesh Bureau of Statistics (BBS), 2005. Statistical year book. Bangladesh Bureau of Statistics, Dhaka, Government of People's Republic of Bangladesh.

Devidson, J. 1984. Research in the Forest Management Branch of the BFRI. UNDP/FAO, BGD/79/017, Field Document No. 4.

Forest Department (FD), 2012. Bangladesh Forest Department Conservation sites. Ministry of environment and Forests, Government of Bangladesh. Available at URL: http://www.bforest.gov.bd, last accessed on 20.08.2012.

Fillius, A. M. 1982. Economic aspects of agroforestry. Agroforestry Systems, 1 (1): 29-39.

Government of Bangladesh (GoB), 1990. Resource Information Management System Data Bank. Forest Department, Mohakhali, Dhaka.

World Bank 2001. World Development Report 2000/2001: Attacking Poverty. Washington DC, the World Bank. 